\title{
Pengaruh Pemberian Pupuk Kandang Ayam Terhadap Pertumbuhan dan Hasil Tanaman Bayam Merah (Amaranthus Tricolor L.)
}

\author{
Adrianus Raja ${ }^{1}$, Henderikus Darwin Beja ${ }^{2}$, Julianus Jeksen ${ }^{3}$ \\ 1,2,3 Universitas Nusa Nipa \\ *Email: adrianusraja27@gmail.com ${ }^{2}$ darwinbeja@ymail.com
}

\begin{abstract}
Abstrak
Tanaman Bayam Merah (Amaranthus tricolor L.)merupakan tanaman yang daunnya biasadikonsumsi sebagai sayuran. Hal ini terlihat dari besarnya permintaaan akan sayuran ini di beberapasupermarket, hotel dan restoran. Tujuan dari penelitian ini adalah untuk mengetahui pengaruh pupuk kandang ayam terhadap pertumbuhan dan hasil tanaman bayam merah, serta mengetahui dosis optimum pupuk kandang yang dapat memberikan pertumbuhan dan hasil tanaman bayam merah (Amaranthus tricolor L.) yang optimal. Metode yang digunakan dalam penelitian ini adalah Rancangan Acak Kelompok (RAK) dengan enam perlakuan dan empat ulangan yaitu : PKO : 0 ton/ha, PK1 : 20 ton/ha, PK2 : 30 ton/ha, PK3 : 40 ton/ha, PK4 : 50 ton/ha, PK5 : 60 ton/ha. Berdasarkan hasil analisis sidik ragam menggunakan rancangan acak kelompok (RAK) hasil penelitian diperoleh bahwa pemberian pupuk kandang ayam tidak berpengaruh nyata terhadap tinggi tanaman dan jumlah daun tanaman bayam merah, namun berpengaruh nyata terhadapberat segar tan ${ }^{-1}$ dan berat segar $\mathrm{ha}^{-1}$. Dosis pupuk kandang ayam 30 ton/ha merupakan perlakuan pupuk terbaik untuk hasil tanaman bayam merah (Amaranthus tricolor L.) yang optimal dengan rata-rata produksi 24,68 ton/ha.
\end{abstract}

Kata Kunci : Tanaman Bayam Merah; Pupuk Kandang Ayam

\section{Pendahuluan}

Tanaman bayam merah (Amaranthus tricolor L.) merupakan tanaman yang daunnya biasadikonsumsi sebagai sayuran. Tanaman ini berasal dari Amerika dan sekarang telah tersebar keseluruh dunia. Sayuran ini mempunyai nilai ekonomis tinggi dibandingkan dengan beberapajenis bayam lainnya. Hal ini terlihat dari besarnya permintaaan akan sayuran ini di beberapasupermarket, hotel dan restoran.

Tanaman bayam merah (Amaranthus tricolor L.) sebagai tanaman sayuran telah banyakdiminati masyarakat karena memiliki kandungan gizi yang tinggi. Seperti protein, vitamin $\mathrm{A}$, vitamin $\mathrm{C}$, garam-garam mineral dan antosianin. Selain itu tanaman inimemiliki keunggulan yaitu dapat dijadikan sebagai obat pembersih darah setelah melahirkan,memperkuat akar rambut, mengobati disentri, dan mengatasi anemia. Keberadaan bayam merahsebagai salah satu komoditi sayuran sangat dibutuhkan dalam penyempurnaan gizi masyarakat. Kandungan gizi tanaman bayam merah antara lain protein, vitamin A, vitamin $\mathrm{C}$, garam-garammineral dan antosianin yang berguna dalam menyembuhkan penyakit anemia.

Menurut data Badan Pusat Statistik Indonesia tahun 2017 produksi tanaman bayam merah sebanyak 40.608 ha mencapai148.288 ton, jika dibandingkan dengan data produksi tanaman bayam merah pada tahun 2016 maka terjadi penurunan tingkat produksi sebanyak 43.456 mencapai 160.247 ton. Penurunan tingkat produksi tanaman bayam merah ini dipengaruhi oleh beberapa faktor di antaranya aspek budidaya, penggunaan bibit unggul dan pemupukan.

Untuk meningkatkan produksi telah banyak dilakukan pemerintah. Beberapa teknik budidaya yangtelah diterapkan adalah penggunaan bibit unggul, Penggunaan pupuk organik di kalangan petani ternyata lebihdisukai, dan tanpa penggunaan secara terus menerus justru merusak lingkungan tanah danmenurunkan produksi.
Pupuk organik merupakan pilihan yang tepat memperbaiki komoditi,kerusakan tanah dan diyakini berdampak baik terhadap peningkatan produksi.

Pupuk dibedakan menjadi dua yaitu pupuk organik dan anorganik. Pupuk organik adalah pupuk yang terbuat dari sisa mahkluk hidup yang diolah melalui proses pembusukan atau dekomposisi oleh bakteri pengurai. Sedangkan pupuk anorganik adalah jenis pupuk yang dibuat oleh pabrik dengan cara meramu berbagai bahanbahan kimia sehingga memiliki presentasi kandungan hara yang tinggi (Novizan, 2002).

Pupuk kandang ayam merupakan pupuk yang berasal dari kotoran ternak ayam, sisamakanan ayam dan alas kandangnya. Pupuk kandang ayam disebut juga pupuk lengkap karenamengandung hampir semua jenis hara. Beberapa hara yang dikandung pupuk kandang ayamadalah $57 \% \mathrm{H}_{2} \mathrm{O}, 29 \%$ bahan organik, $1,5 \% \mathrm{~N}, 1,3 \%$ $\mathrm{P}_{2} \mathrm{O}_{3}, 0,8 \% \mathrm{~K}_{2} \mathrm{O}, 4 \% \mathrm{CaO}$ dan memilikirasio $\mathrm{C} / \mathrm{N}$ 9-11 (Hartatik dan Widowati, 2010). Pupuk kandang ayam dapat memperbaiki sifatfisik tanah dimana penggunaan pupuk ini dapat menggemburkan tanah, meningkatkan aerasi danmeningkatkan kemampuan tanah memegang air. Pupuk kandang ayam juga dapat memperbaikisifat kimia tanah seperti meningkatkan bahan organik $\mathrm{C}, \mathrm{N}, \mathrm{P}$, serta menurunkan Al dan logamberat. Selanjutnya pupuk kandang ayam dapat meningkatkan dan memperbaiki sifat biologi tanah karena pupukkandang ayam sebagai bahan makanan mikroorganisme yang ada dalam tanah (Anonim, 2014).

\section{Metodologi}

Penelitian ini dilaksanakan di kebun Praktek Fakultas Pertanian Universitas Nusa Nipa Maumere. Jalan Litbang, Kelurahan Kota Uneng, Kecamatan Alok, Kabupaten Sikka, Nusa Tenggara Timur. Kegiatan penelitian dilaksanakan mulai dari bulan November sampai Desember 2020. 
Data hasil pengamatan dianalisis sesuai dengan Rancangan Acak Kelompok (RAK) yang digunakan, apabila perlakuan menunjukkan pengaruh nyata atau sangat nyata terhadap variabel yang diamati, maka dilakukan uji beda nyata terkecil (BNT) pada taraf 5\%(Gomez dan Gomez, (1995) ).

\section{Hasil}

Hasil analisis data statistik menunjukan bahwa pemberian pupuk kandang ayam tidak memberikan pengaruh nyata terhadap tinggi tanaman bayam merah dan jumlah daun tanaman bayam merah, namun berpengaruh nyata terhadap berat segar $\tan ^{-1}$, dan berat segar ha-1 pada tanaman bayam merah.

Tabel 1. Signifikasi Pengaruh Pemberian Pupuk Kandang Ayam Terhadap Pertumbuhan dan Hasil Tanaman Bayam Merah

\begin{tabular}{lll} 
No & \multicolumn{1}{c}{ Variabel } & Signifikasi \\
\hline 1. & Tinggi tanaman umur 7 hst & TN \\
\hline 2. & Tinggi tanaman umur $14 \mathrm{hst}$ & $\mathrm{TN}$ \\
\hline 3. & Tinggi tanaman umur $21 \mathrm{hst}$ & $\mathrm{TN}$ \\
\hline 4. & Jumlah daun umur $7 \mathrm{hst}$ & $\mathrm{TN}$ \\
\hline 5. & Jumlah daun umur $14 \mathrm{hst}$ & $\mathrm{TN}$ \\
\hline 6. & Jumlah daun umur $21 \mathrm{hst}$ & $\mathrm{TN}$ \\
\hline 7. & Berat segar tan ${ }^{-1}$ & $*$ \\
\hline 8. & Berat segar ha ${ }^{-1}$ & $*$ \\
\hline
\end{tabular}

Keterangan

TN : Tidak Nyata

* : Nyata

Hasil analisis sidik ragam menunjukan bahwa pemberian pupuk kandang ayam tidak berpengaruh terhadap variabel pertumbuhan tanaman bayam merah (Amaranthustricolor L.) yaitu pada tinggi tanaman dan jumlah daun tanaman bayam merah (Amaranthustricolor L.).
Tabel 2. Pengaruh Pemberian Pupuk Kandang Ayam Terhadap Pertumbuhan Tinggi Tanaman dan Jumlah Daun

\begin{tabular}{|c|c|c|c|c|}
\hline \multirow[t]{2}{*}{ Variabel } & \multirow{2}{*}{$\begin{array}{c}\text { Pelaku } \\
\text { an }\end{array}$} & \multicolumn{3}{|c|}{ Umur Pengamatan (hst) } \\
\hline & & 7 & 14 & 21 \\
\hline \multirow{6}{*}{$\begin{array}{c}\text { Tinggi } \\
\text { Tanaman }\end{array}$} & PK 0 & $4,28 \mathrm{a}$ & $10,13 \mathrm{a}$ & $11,26 \mathrm{a}$ \\
\hline & PK 1 & $4,29 \mathrm{a}$ & $9,71 \mathrm{a}$ & $10,64 \mathrm{a}$ \\
\hline & PK 2 & $3,67 \mathrm{a}$ & $10,69 \mathrm{a}$ & $11,49 \mathrm{a}$ \\
\hline & PK 3 & $4,10 \mathrm{a}$ & $10,45 \mathrm{a}$ & $11,02 \mathrm{a}$ \\
\hline & PK 4 & $5,21 \mathrm{a}$ & $11,29 \mathrm{a}$ & $12,10 \mathrm{a}$ \\
\hline & PK 5 & $4,78 \mathrm{a}$ & $11,40 \mathrm{a}$ & $12,16 \mathrm{a}$ \\
\hline \multirow{6}{*}{$\begin{array}{l}\text { Jumlah } \\
\text { Daun }\end{array}$} & PK 0 & $2,60 \mathrm{a}$ & $6,58 \mathrm{a}$ & $9,96 \mathrm{a}$ \\
\hline & PK 1 & $3,20 \mathrm{a}$ & $7,49 \mathrm{a}$ & $10,49 \mathrm{a}$ \\
\hline & PK 2 & $3,59 \mathrm{a}$ & $6,79 \mathrm{a}$ & $10,38 \mathrm{a}$ \\
\hline & PK 3 & $3,14 \mathrm{a}$ & $6,67 \mathrm{a}$ & $10,66 \mathrm{a}$ \\
\hline & PK 4 & $3,47 \mathrm{a}$ & $7,14 \mathrm{a}$ & $10,81 \mathrm{a}$ \\
\hline & PK 5 & $3,72 \mathrm{a}$ & $7,92 \mathrm{a}$ & $11,93 \mathrm{a}$ \\
\hline
\end{tabular}

Keterangan : Angka-angka yang diikuti oleh huruf yang sama pada kolom yang sama menunjukan tidak berbeda nyata pada taraf uji BNT 5\%.

Tabel 3. Pengaruh Pupuk Ayam Terhadap BS Tan'-1, BS $\mathrm{Ha}^{-1}$ Tanaman Bayam Merah.

\begin{tabular}{ccc}
\hline Perlakuan & \multicolumn{2}{c}{ Variabel hasil } \\
\cline { 2 - 3 } & BS TAN $^{-1}$ & BS HA $^{-1}$ \\
\hline PK 0 & $9,43 \mathrm{c}$ & $25,10 \mathrm{c}$ \\
\hline PK 1 & $8,60 \mathrm{a}$ & $22,93 \mathrm{a}$ \\
\hline PK 2 & $9,26 \mathrm{~b}$ & $24,68 \mathrm{~b}$ \\
\hline PK 3 & $9,65 \mathrm{~d}$ & $25,73 \mathrm{~d}$ \\
\hline PK 4 & $10,31 \mathrm{e}$ & $27,49 \mathrm{e}$ \\
\hline PK 5 & $11,06 \mathrm{f}$ & $29,48 \mathrm{f}$ \\
\hline
\end{tabular}

Keterangan : Angka-angka yang diikuti huruf yang sama pada kolom yang sama yang menunjukan tidak berbeda nyata pada taraf uji BNT $5 \%$.

BS TAN ${ }^{-1}$ : Berat segar per tanaman

BS HA $^{-1}$ : Berat segar per hektar 
Hasil analisis sidik ragam menunjukan bahwa pemberian pupuk kandang ayam tidak berpengaruh nyata terhadap tinggi tanaman dan jumlah daun pada tanaman bayam merah. Pernyataan ini menunjukan bahwa hipotesis 1 ditolak karena tidak memberikan pengaruh nyata terhadap pertumbuhan tinggi tanaman dan jumlah daun, artinya bahwa secara keseluruhan mempunyai hasil yang sama. Pemberian pupuk kandang ayam membuktikan bahwa perlakuan tanpa pupuk kandang ayam atau $0 \mathrm{~kg} \mathrm{ha}^{-}$ ${ }^{1}(\mathrm{PK} 0)$, memberikan hasil rata-rata yang sama dengan perlakuan yang lainnya(PK1, PK2, PK3, PK4, dan PK5). Menurut Aris (2005). Hal ini disebabkan oleh besarnya laju transpirasi yang dipengaruhi oleh faktor lingkungan seperti suhu pada siang hari dan kelembapan udara yang rendah, selain itu juga keadaan tanah yang mengering pada cuaca yang panas dengan sifat fisik tanah yang padat dan rendahnya kandungan air dalam tanah yang menyebabkan akar sukar menembus tanah akibat difusi $\mathrm{O}_{2}$ berlangsung lambat (Leiwakabessy, 1988). Kurangnya air dapat mengganggu proses fotosintesis, sehingga pertumbuhan tanaman seperti tinggi tanaman dan pembentukan daun menjadi terhambat (Dwidjosepurto, 1992).

Pupuk kandang ayam juga mengandung unsur nitrogen yang merupakan pembatas utama pertumbuhan dan hasil tanaman bayam merah. Nitrogen dibutuhkan tanaman selalu tinggi ketimbang dari unsur hara lain, namun kekurangan atau kelebihan dapat menghambat dan mengganggu pertumbuhan tanaman. Menurut Tarigan $d k k$.(2010) menyatakan bahwa nitrogen yang dibutuhkan dalam jumlah relatif besar pada setiap pertumbuhan tanaman khususnya pertumbuhan vegetatif tanaman, karena nitrogen merupakan bahan pembangun protein, asam nukleat anzim dan alkaloid.Perananan utama nitrogen pada tanaman adalah untuk merangsang pertumbuhan batang, cabang dan daun yang menjadi fase generatif tanaman.Tanaman yang mengalami pertumbuhan yang baik dan membentuk daun dengan sempurna maka proses pertumbuhan tanaman bayam merah juga akan maksimal. Dari hasil penelitian Nursyamsidkk. (1996) melaporkan peningkatan takaran nitrogen secara nyata dapat meningkatkan tinggi tanaman. Namun pemupukan nitrogen yang terlalu tinggi mengakibatkan kadar karbohidrat menurun dan tanaman tidak berkualitas.

Hasil analisis sidik ragam menunjukan bahwa dosis pupuk kandang ayam memberikan pengaruh nyata terhadap berat segar ${ }^{-1}$ tan dan berat segar ha-1 pada tanaman bayam merah (Amaranthustricolor L.)

Hasil analisis sidik ragam menunjukan bahwa pengaruh pemberian pupuk kandang ayam terhadap berat segar $\tan ^{-1}$ dan berat segar ha-1 menujukan pengaruh nyata. Hasil tertinggi diperoleh pada perlakuan pemberian pupuk kandang ayam 60 ton/ha (PK5) dengan hasil rata-rata 88,48 ton/ha dan hasil terendah diperoleh pada pemberian pupuk kandang ayam 0 ton/ha atau tanpa pupuk (PK0) dengan hasil rata-rata 68,82 ton/ha, terjadi peningkatan hasil sebesar 22,21\%. Jika dibandingkan antara kedua perlakuan tersebut atau memiliki selisi sebesar 19,66 ton. Pernyataan ini menunjukan bahwa hipotesis 1 di terima karena pupuk kandang ayam memberikan pengaruh terhadap berat segar $\tan ^{-1}$ dan berat segar ha- ${ }^{-1}$. Perlakuan di atas menunjukan hasil yang terbaik karena berdasarkan hasil uji beda rata-rata menggunakan uji beda nyata terkecil (BNT) 5\% sedangkan hasil terendah diperoleh pada perlakuan pemberian pupuk kandang ayam dosis 0 ton/ha (PK0) dengan hasil rata-rata 68,82 ton/ha. Pernyataan ini menunjukan bahwa hipotesis 2 ditolak.

Wigati $d k k$ (2006) peningkatan efisiensi pemupukan dapat dilakukan dengan pemberian bahan organik yang banyak tersedia disekitar petani adalah pupuk kandang. Pemberian pupuk kandang dapat mengurangi penggunaan dan meningkatkan efisiensi penggunaan pupuk organik juga akan menyumbangkan usur hara bagi tanaman serta meningkatkan sarapan unsur hara oleh tanaman. Pupuk kandang ayam mengandung unsur $\mathrm{N}, \mathrm{P}$, dan $\mathrm{K}$ yang tinggi, juga mengandung $\mathrm{Ca}$ dan $\mathrm{Mg}$. Adanya unsur nitrogen yang berfungsi sebagai aktifator berbagai enzim dan molekul khlofil, radium berfungsi sebagai aktifator berbagai ensim sintesa protein maupun metabolisme karbohidrat, fosfor berperan aktif dalam mentransfer energi didalam sel tanaman dan magnesium sebagai penyusun klororfil dan membantu translokasi fosfor dalam tanaman, pemberian kalium pada bayam merah yang mempengaruhi pertumbuhan dan hasil tanaman bayam merah yang berkualitas baik. Hal ini menunjukan bahwa terjadi penyerapan hara yang lebih efektif dan pembentukan fotosintet yang lebih besar sehingga dapat menghasilkan tanaman bayam merah yang lebih baik dan optimal.

Umbo dan Andre (1997) menyatakan bahwa penyerapan unsur hara yang tinggi menyebabkan proses fotosintesa juga akan tinggi pula dan hal ini akan meningkatkan pertumbuhan tiap pada tanaman yang dibudidaya. Dan selanjutnya Ali (2011) menyatakan bahwa pertumbuhan perkembangan dan hasil suatu tanaman akan meningkat apabila pasokan unsur hara tidak menjadi faktor pembatas. Irfan (2013) penambahan hara mikro dan makro, protein, vitamin dan ZPT seharusnya sangat berpengaruh pada peningkatan pertumbuhan dan produksi tanaman. Pemberian pupuk organik atau pupuk $\mathrm{N}$, P, dan $\mathrm{K}$ sangat berpengaruh penting dalam proses pertumbuhan pada tanaman.

\section{Kesimpulan}

Pemberian pupuk kandang ayam tidak berpengaruh nyata terhadap tinggi tanaman dan jumlah daun pada tanaman bayam merah, tetapi berpengaruh nyata terhadap berat segar $\tan ^{-1}$ dan berat segar ha ${ }^{-1}$ dengan produksi ratarata mencapai 24,68 ton/ha.

Dosis optimum pupuk kandang ayam 30 ton/ha merupakan perlakuan terbaik untuk hasil tanaman bayam merah (Amaranthustricolor L.) yang optimal dengan produksi mencapai 24,68 ton/ha.

\section{Daftar Pustaka}

Anggayuhlin, R. 2012. Studi Populasi Tanaman terhadap PeningkatanProduktivitas dan Konsumsi Air Tanaman Bayaman (Amaranthus tricolorL.) Pada Teknik Hidroponik. Skripsi. Bogor. Departemen Agronomi danHortikultura. Fakultas Pertanian. Institut Pertanian Bogor.

Agromedia Redaksi. 2007. Petunjuk Pemupukan. Jakarta: Agromedia Pustaka. 
Akhda, D. K. N.. 2009. Pengaruh dosis dan waktu aplikasi komposAzolla sp.Terhadap pertumbuhan tanaman bayam merah (Alternantheraamoena voss). Skripsi fakultas sains dan teknologi. UIN Malang.

Bandini, Y dan N Aziz. 2001. Bayam. Jakarta: Penebar SwadayaBPS. 2017. StatistikTanamanSayurandanBuah-BuahanSemusim Indonesia.

BPS. 2017. Statistik Tanaman Sayuran dan Buah-Buahan Semusim Indonesia.Badan Pusat Statistik. http://www.bps.go.id [10 Oktober 2018].

Dinas Pertanian Provinsi Nusa Tenggara Timur. 2017. Keadaan Luas Tanam, Luas Panen, Produksi dan Produktifitas Komoditi Sayur-Sayuran.

http://distan.nttprov.go.id./wpcontent/uploads/2018/11/ATAPHorti-2017-SAYUR.pdf. Diambil tanggal 04 Oktober 2019 jam 13:23.

Dwidjosepurto. 1992. Pengantar Fisiologi Tumbuhan. PT . Gramedia Pustaka Utama: Jakarta.

Fazria, $\quad$ M. A. 2011. Pengukuran Zat besi dalam bayam merah dan suplemen penambah darah serta penanganan terhadap peningkatan hemoglobin dan zat besi dalam darah. [Skripsi] Universitas Indonesia, Depok.

Gardner, F. P., Brent P. R, dan Roger L. Mitchell. 2008. Fisiologi TanamanBudidaya. Penerjemah: Herawati Susilo. Pedamping: Subiyanto. Jakarta.UI Press. Terjemahan Physiology of Crop Plants.

Gomez. K.A and A.A.Gomez. 2005. Statistical Procedures For AgriculturalResearch. Jhon Wiley And Sons. New York.

Hartatik dan L.R. Widowati. 2010. Pupuk Organik dan Pupuk Hayati.http://www.balittanah.litbang.deptan.go.id. Diakses 30 Mei 2015.

Ismawati.2007.pupuk oraganik,penebar swadaya.jakarta.72hal.

Kementerian Pertanian.2019.Sekretariat Direktorat Jenderal Hortikultura. http://holtikultura2.pertanian.go.id./produksi/sayuran.php.

Kusumawati, Aditya. 2013. "Kualitas Es Krim Gembili (Dioscorea esculentaLour) Dengan Penambahan Daun Bayam Merah (Alternanthera amoena Voss) (Skripsi S1- Progdi Biologi). Surakarta: FKIP Universitas Muhammadiyah Surakarta

Lingga, P. Dan Marsono. 2001. Petunjuk Penggunaan Pupuk, Penebar Swadaya. Jakarta.

Leiwakabessy, F. M. 1988. Diktat Kuliah Kesuburan Tanah. Departemen Tanah. Fakultas PeranianIPB. Bogor.

Munawar Ali 2011. Kesuburan Tanah dan Nutrisi Tanaman. IPB Press. Bogor. 130 hlm.

Nursyamsi, dkk. 1996. Penggunaan Bahan Organik Untuk Meningkatkan Efesiensi Pupuk N pada Ultisol Sitiung. Sumatra Barat. Pros. Seminar Sumberdaya Lahan (Buku) Puslitanak, Bogor. Hal. 319-330

Novizan, 2002. Petunjuk Pemupukan yang Efektif. Agromedia Pustaka. Jakarta.Hartatik dan L.R. Widowati. 2010. Pupuk Organik dan Pupuk Hayati.

http://www.balittanah.litbang.deptan.go.id. Diakses 30 Mei 2015 . 